\title{
https://doi.org/10.46813/2021-131-141 \\ THE INTERACTION OF A SUPERSONIC PLASMA JET CONTAINING NANOPARTICLES WITH A SUBSTRATE
}

\author{
O.Yu. Kravchenko, I.S. Maruschak \\ Taras Shevchenko National University of Kyiv, Kyiv, Ukraine \\ E-mail:kay@univ.kiev.ua
}

In the framework of a multi-fluid axisymmetric hydrodynamic model, the interaction of a supersonic plasma jet containing nanoparticles with a flat substrate is investigated using computer simulation. In particular, the fluxes of nanoparticles on the substrate are studied at plasma inlet pressure $\mathrm{P}_{0}=1 \ldots 100$ Torr. The results show that a shock wave is formed near the substrate, which affects the energy of nanoparticles and their fluxes on the substrate. The width of the region along the radius, where the flow of nanoparticles onto the substrate is essential, depends on the plasma pressure in the jet. At large values of plasma pressure $\left(\mathrm{P}_{0} \geq 75\right.$ Torr $)$ a cloud of nanoparticles with a sharp boundary is formedon the axis of the plasma jet near the substrate. Interacting with this cloud, nanoparticles moving in the plasma jet, lose directed energy and their flow on the substrate near the axis of the jet is zero.

PACS: 52.27.Lw

\section{INTRODUCTION}

Plasma-assisted technologies represent important toolsfor deposition of nano-structured films on substrates. The growth ofthin and ultra-thin films may be achieved using a large variety oftechniques such as chemical vapour deposition, RF sputtering, pulsedlaser deposition or plasma enhanced chemical vapour deposition [1-3]. Recently, a new process, which uses aplasma torch operating at low pressure has been developed with theaim of depositing uniform thin layers on large surfaces $[4,5]$. In this plasma spraying process plasma jets areused as a heat sources to melt and accelerate the injected nanoparticles which subsequently impinge and solidify on a substrate. Modelling the nanoparticles, which create and assemble the film it is possible to enhance the physical properties of thinfilms. It is important to beable to control the kinetic energy of nanoparticles, their temperature and the magnitude of the flow on the substrate. Inorder to control efficiently the technological parameters of theplasma's action, it is necessary to calculate the plasma flowcharacteristics by means of the proper mathematical model.

The problem of the expansion of a plasma jet with dust particles into a space filled with a rarefied gas was studied in within the framework of a multi-fluid model $[6,7]$. However, in order to determine the particle fluxes onto the substrate, it is necessary to take into account the interaction of the plasma jet with this substrate. The aim of this work is to numerically model the interaction of an axisymmetric plasma jet containing nanoparticles with a substrate, as well as to study the fluxes of nanoparticles on a substrate at various plasma pressures at the inlet.

\section{MODEL AND SIMULATION METHOD}

In this paper, the expansion of an axially symmetric plasma jet with nanoparticles into a rarefied neutral gas and its interaction with the substrate are studied. The plasma consists of neutral argon atoms, single charge ions, electrons and dust particles. This study is uses the 2D hydrodynamics model described in [7]. In the model ions, electrons and neutral atoms have the same drift velocity $\vec{w}=(u, v)$ due to effective momentum exchange, and dustparticles have drift velocity $\vec{w}_{d}=\left(u_{d}, v_{d}\right)$. Here $u, u_{d}$ are radial velocity components and $v, v_{d}$ are axial velocity components. The ions temperature equals to neutral atoms temperature $T$, but electrons temperature $T_{e}$ can differ from them.

This model includes equations of continuity, equations of moments, as well as energy conservation equations for various plasma components: ions, electrons, neutral atoms, nanoparticles.

The equations of continuity are written in the form

$$
\begin{aligned}
& \frac{\partial n}{\partial t}+\operatorname{div}(n \vec{w})=0 . \\
& \frac{\partial n_{i}}{\partial t}+\operatorname{div}\left(n_{i} \vec{w}\right)=-I_{i} n_{d} / e, \\
& \frac{\partial n_{d}}{\partial t}+\operatorname{div}\left(n_{d} \vec{w}_{d}\right)=0 .
\end{aligned}
$$

Here $n_{i}, n_{d}$ are ions and nanoparticles densities, $n$ is sum of ions and neutral atoms densities, $I_{i}$ is ion current on a dust particle [8].

Momentum equations for heavy plasma particles (ions and atoms) and dust particles are of the form

$$
\begin{aligned}
& \frac{\partial(n u)}{\partial t}+\operatorname{div}(n u \vec{w})=-\frac{1}{m_{i}} \frac{\partial P}{\partial r}-\frac{n_{d} f_{r}}{m_{i}}+\frac{e}{m_{i}} n_{i} E_{r}, \\
& \frac{\partial(n v)}{\partial t}+\operatorname{div}(n v \vec{w})=-\frac{1}{m_{i}} \frac{\partial P}{\partial z}-\frac{n_{d} f_{z}}{m_{i}}+\frac{e}{m_{i}} n_{i} E_{z}, \\
& \frac{\partial\left(n_{d} u_{d}\right)}{\partial t}+\operatorname{div}\left(n_{d} u_{d} \vec{w}_{d}\right)=-\frac{\alpha_{d}}{m_{d}} \frac{\partial P}{\partial r}+\frac{n_{d} f_{r}}{m_{d}}+\frac{q_{d}}{m_{d}} n_{d} E_{r}, \\
& \frac{\partial\left(n_{d} v_{d}\right)}{\partial t}+\operatorname{div}\left(n_{d} v_{d} \vec{w}_{d}\right)=-\frac{\alpha_{d}}{m_{d}} \frac{\partial P}{\partial z}+\frac{n_{d} f_{z}}{m_{d}}+\frac{q_{d}}{m_{d}} n_{d} E_{z} .
\end{aligned}
$$

Here $P, P_{e}$ are partial pressures of the heavy plasma component and electrons, $f_{r}$ and $f_{z}$ are radial and axial components of friction force between plasma and 
nanoparticles [8], $q_{d}, m_{d}$ are a charge and mass of a nanoparticle, $m_{i}$ is ion mass, $E_{r}, E_{z}$ are radial and axial components of electric field, $\alpha_{d}$ is volume content of nanoparticles.

Equations for internal energies ions and atoms $\varepsilon$, electrons $\varepsilon_{e}$ and dust particles $\varepsilon_{d}$ are written in the form

$$
\begin{gathered}
\frac{\partial(\rho \varepsilon)}{\partial t}+\operatorname{div}(\rho \varepsilon \vec{w})+P \operatorname{div} \vec{w}=Q_{e i}+Q_{e n}-n_{d} Q, \\
\frac{\partial\left(\rho \varepsilon_{e}\right)}{\partial t}+\operatorname{div}\left(\rho \varepsilon_{e} \vec{w}\right)+P_{e} \operatorname{div} \vec{w}+\operatorname{div} q_{e}= \\
-Q_{e i}-Q_{e n}-n_{d} Q_{e d}, \\
\frac{\partial\left(\rho_{d} \varepsilon_{d}\right)}{\partial t}+\operatorname{div}\left(\rho_{d} \varepsilon_{d} \vec{w}_{d}\right)=n_{d} Q+n_{d} Q_{e d}+Q_{i d} .
\end{gathered}
$$

These equations take into account the momentum and energy exchange between nanoparticles and plasma particles due to collisions, as well as radiation from the surface of heated dust particles, which freely leaves the plasma volume. Here $Q, Q_{e d}, \mathrm{Q}_{i d}$ are the energy exchanges between a dust particle and neutral atoms, electrons and ions, $Q_{e i}$ is the energy exchange between electrons and ions, $Q_{e n}$ is the energy exchange between electrons and neutrals [6].

The difference between our model and the model used in [6] consists in the boundary conditions of the problem - we use the conditions of non-leakage on the substrate for the plasma and the conditions of adhesion for the dust component.

As in [6], the system of hydrodynamic equations is solved numerically by the method of large particles [9].

\section{RESULTS AND DISCUSSION}

The numerical simulations of the plasma jet expansion were carried out with the following parameters at the inlet: the plasma flow velocity $v_{0}=40 \mathrm{~m} / \mathrm{s}$, the dust particles radius $r_{d}=5 \cdot 10^{-8} \mathrm{~m}$, the radius of the inlet $R_{0}=0.01 \mathrm{~m}$, the ratio of the densities of the dust component and plasma $\rho_{d} / \rho_{0}=0.1$.

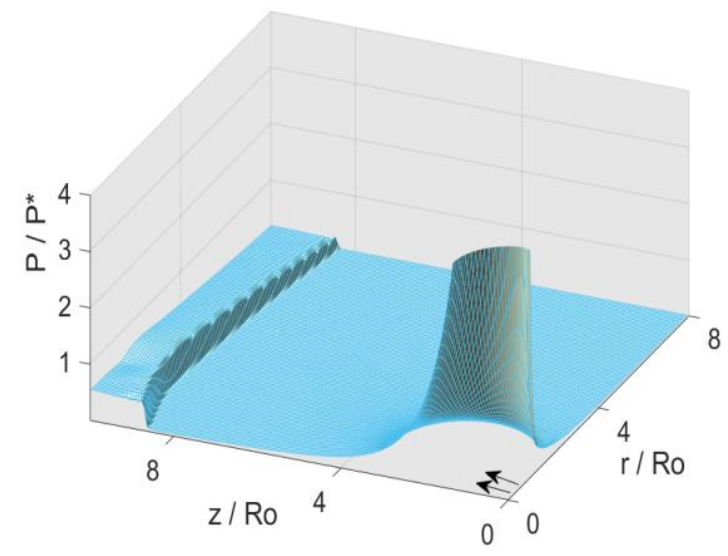

Fig. 1. Spatial distributionof plasma pressure for $P_{0}=100$ Torr at time $t=12 \cdot t_{0}$
Plasma pressureat the inlet varied within $\mathrm{P}_{0}=1 \ldots 100$ Torr The substrate is located at a distance of $\mathrm{L}=0.1 \mathrm{~m}$ from the inlet. The degree of plasma ionization was $\alpha=0.0001$.

As is known, the plasma pressure in an expanding jet decreases with increasing axial and radial coordinates, and the velocities of plasma and nanoparticles increase. However, during the interaction of a supersonic jet with a substrate, a region of increased plasma pressure appears near it. This can be seen from Fig. 1, which shows the spatial distribution of the plasma pressure for case $P_{0}=100$ Torr at time $t=12 \cdot t_{0}$ after the start of the jet injection, where $t_{0}=R_{0} / v_{0}$. Here the pressure is normalized to $P^{*}=\rho_{0} \cdot v_{0}^{2}$, coordinates on $R_{0}$. The figure also shows the formation of a pressure jump at some distance from the substrate, the position of which almostdoes not change over time.
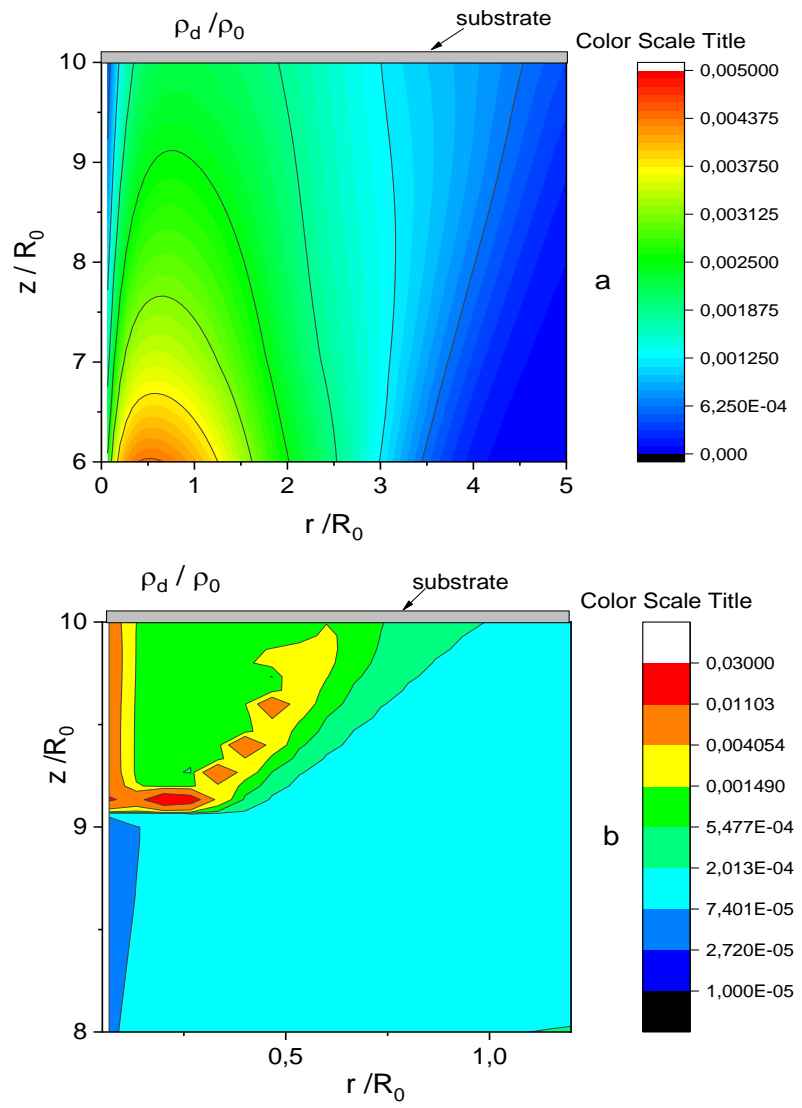

Fig. 2. Spatial distributions of the nanoparticles density for $P_{0}=10$ Torr $(a)$ and for $P_{0}=100$ Torr $(b)$

In this study we focus on the nanoparticles distributions in plasma jets to obtain information about the interaction of nanoparticles with the substrate at different plasma pressures. Fig. 2 shows spatial distributions of nanoparticles density near the substrate. At $P_{0}=10$ Torr , the concentration of nanoparticles decreases monotonically with increasing axial coordinate $z$. However, at plasma pressure at the inlet of 100 Torr formation of dust clouds is observed. In particular, near the substrate nanoparticles are collected on the axis of the jet. 
For a more detailed analysis of the effect of the pressure jump on the flow parameters, consider the spatial distributions of the velocities of plasma and nanoparticles along the axis of the jet, obtained at two different values of plasma pressure $P_{0}$ at the inlet (Fig. 3).

These figures show also the distributions of plasma pressure and nanoparticles density along the axis of the jet at the same time. As can be seen from the figure, the velocities of plasma and dust component increase with increasing coordinate before the plasma pressure jump. The increase of the plasma velocity during the expansion of the plasma into a rarefied gas is due to the conversion of its thermal energy into the energy of directional motion. Moreover, with increasing plasma pressure at the inlet, the plasma velocity increases, which is due to the higher plasma temperature in this case [6]. The velocities of nanoparticles in the jets also increase with increasing coordinates, which is a result of the friction force between the plasma and the dust component. It should be noted thatthe acceleration of nanoparticles significantly depends on $P_{0}$.
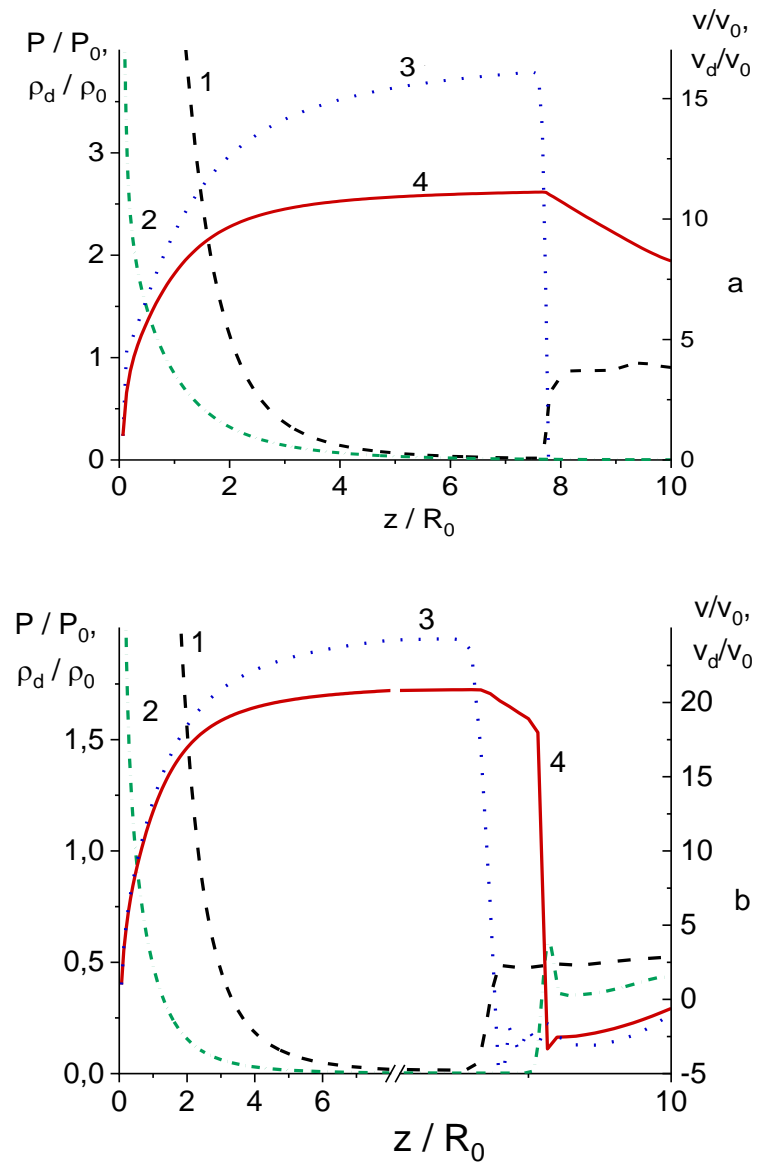

Fig. 3. Spatial distributions of plasma pressure (dash curves 1), dust density (short dash dot curves 2), plasma velocity (dot curves 3 ) and nanoparticles velocity (solid curves 4) on jet axis for $P_{0}=30$ Torr (a) and for $P_{0}=100$ Torr $(b)$

At the pressure jump, the axial component of the plasma velocity decreases sharply, so that behind the jump, a plasma flux reflected from the substrate is observed. The velocity of nanoparticles decreases behind a jump in plasma pressure. In the case of
$P_{0}=30$ Torr it decreases slightly according to a linear law. As a result, in contact with the wall, the velocity of nanoparticles is $v_{d} \approx 5 \cdot v_{0}$. In this mode, the density of nanoparticles decreases monotonically along the axis of the jet. In the case of $P_{0}=100$ Torr a cloud of nanoparticles with a sharp boundary is formed near the substrate, which is closer to the substrate than the plasma pressure jump. The axial component of the velocity of nanoparticles in the region between the jump in plasma pressure and the jump in the concentration of dust particles decreases slowly according to the linear law, and abruptly at the boundary of the dust cloud and becomes negative. Thus, it can be seen that the nanoparticles in the formed cloud move away from the substrate. This is due to the interaction of nanoparticles with a plasma flow reflected from the substrate.

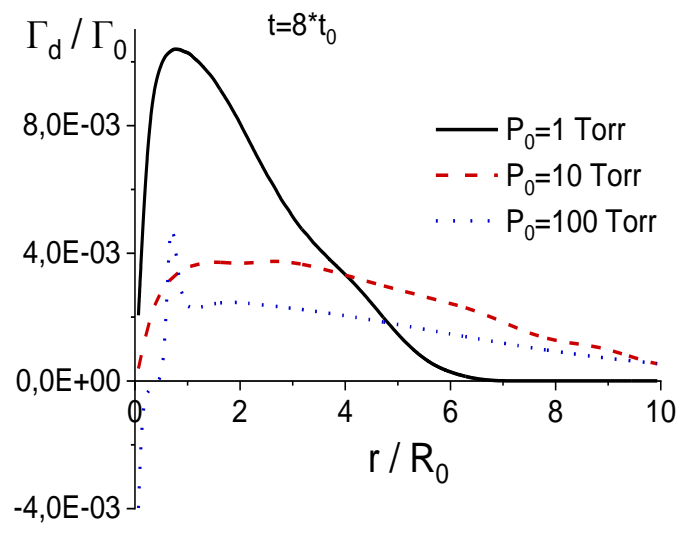

Fig. 4. Radial profiles of the flow of nanoparticles onto the substrate at different values of the plasma pressure at theinlet

Fig. 4 shows the radial distributions of the fluxes of nanoparticles on the substrate at different values of plasma pressure at the inlet. The flows here are normalized to $\Gamma_{0}=\rho_{0} \cdot v_{0}$, where $\rho_{0}$ is nanoparticles density at the inlet. The maximum values of dimensionless flows in all modes are achieved at $r \approx R_{0}$. Note that at $P_{0}=1$ Torr, the flux of nanoparticles onto the substrate at $r>6 \cdot R_{0}$ is practically absent. The reason for this is a significant decrease in the concentration of nanoparticles along the radius in the plasma jet in this case. At $P_{0}=100$ Torr, there is no flux to the substrate near the jet axis at $r<0.5 \cdot R_{0}$. This is due to the formation of a cloud of nanoparticles, as indicated above.

\section{CONCLUSIONS}

The interaction of a plasma jet containing nanoparticles with a substrate has been studied using computer simulation. The spatial distributions of the parameters characterizing the arising plasma flow at various values of the plasma pressure at the inlet are obtained. It is shown that when the jet interacts with the 
substrate, a plasma pressure jump appears in front of it, which affects the nanoparticle fluxes onto the substrate. The width of the region along the radius, where the flow of nanoparticles onto the substrate is essential, depends on the plasma pressure in the jet. With increasing pressure, it increases, which is explained by the radial acceleration of nanoparticles under the action of the friction force. At sufficiently high plasma pressures, clouds of nanoparticles with a sharp boundary are formed near the substrate on the jet axis. Nanoparticles accelerated by a plasma jet, when interacting with this cloud, abruptly lose their directed velocity. As a result, there is no flow of nanoparticles onto the substrate at the place of cloud formation.

\section{REFERENCES}

1. P. Roca i Cabarrocas, N. Chaabane, A.V. Kharchenko, and S. Tchakarov. Polymorphous silicon thin films produced in dusty plasmas: application to solar cells // Plasma Phys. Controlled Fusion. 2004, v. 46, p. 235.

2. N.M. Hwang, D.K. Lee. Charged nanoparticles in thin film and nanostructure growth by chemical vapour deposition // J. Phys. 2010, D 43:483001.
3. N. Chaabane, V. Suendo, H. Vach, P. Roca i Cabarrocas. Soft landing of silicon nanocrystalsin plasma enhanced chemical vapor deposition // Appl. Phys. Lett. 2006, v. 88, p. 2031111.

4. I. Biganzoli, F. Fumagalli, F. Di Fonzo, R. Barni, C. Riccardi. A Supersonic Plasma Jet Source for Controlled and Efficient Thin Film Deposition // J. Mod. Phys. 2012, v. 3, p. 1626-1638.

5. V. Trifiletti, R. Ruffo, C. Turrini, D. Tassetti, R. Brescia, F. Di Fonzo, C. Riccardi, A. Abbotto // J. Mater. Chem. 2013, v. A 1, p. 11665.

6. O.Yu. Kravchenko, I.S. Maruschak. Dynamics of dust particles in a plasma jet // Problems of Atomic Science and Technology. Series «Plasma Physics». 2017, № 1, p. 159-162.

7. O.Yu. Kravchenko, I.S. Maruschak. Coagulation and Dynamics Nanoparticles in low Pressure Plasma Jets // Problems of Atomic Science and Technology. Series «Plasma Physics». 2019, № 1, p. 172-175.

8. P.K. Shukla, A.A. Mamun. Introduction to Dusty Plasma Physics. Bristol and Philadelphia: "IoP Publishing Ltd", 2002.

9. O.M. Belozerkovskiy, Yu.M. Davydov. Metod krupnyh chastiz v gasovoj dinamike. M.: "Nauka", 1982, 392 p. (in Russian).

Article received 12.01.2021

\section{ВЗАИМОДЕЙСТВИЕ С ПОДЛОЖКОЙ СВЕРХЗВУКОВОЙ ПЛАЗМЕННОЙ СТРУИ, СОДЕРЖАЩЕЙ НАНОЧАСТИЦЫ}

\section{А.Ю. Кравченко, И.С. Марущчак}

В рамках многожидкостной осесимметричной гидродинамической модели исследуется взаимодействие сверхзвуковой струи плазмы, содержащей наночастицы, с плоской подложкой с помощью компьютерного моделирования. В частности, потоки наночастиц на подложку изучаются при плазменном давлении на входе $\mathrm{P}_{0}=1 \ldots 100$ Торр. Результаты показывают, что вблизи подложки образуется ударная волна, которая влияет на энергию наночастиц и их потоки на подложку. Ширина области по радиусу, в которой поток наночастиц на подложку существенен, зависит от давления плазмы в струе. При больших значениях плазменного давления $\left(\mathrm{P}_{0} \geq 75\right.$ Торр) на оси плазменной струи вблизи подложки образуется сгусток наночастиц с резкой границей. Взаимодействуя с этим сгустком, наночастицы, которые движутся в плазменной струе, теряют направленную энергию, и их поток на подложку вблизи оси струи равен нулю.

\section{ВЗАСМОДІЯ 3 ПІДКЛАДКОЮ НАДЗВУКОВОГО ПЛАЗМОВОГО СТРУМЕНЮ, ЩО МІСТИТЬ НАНОЧАСТИНКИ}

\section{О.Ю. Кравченко, І.С. Марущак}

У рамках багаторідинної осесиметричної гідродинамічної моделі досліджується взаємодія надзвукового струменя плазми, що містить наночастинки, 3 плоскою підкладкою за допомогою комп'ютерного моделювання. Зокрема, потоки наночастинок на підкладку вивчаються при плазмовому тиску на вході $\mathrm{P}_{0}=1 . .100$ Торр. Результати показують, що поблизу підкладки утворюється ударна хвиля, яка впливає на енергію наночастинок та іх потоки на підкладку. Ширина області по радіусу, де потік наночастинок на підкладку є суттєвим, залежить від тиску плазми в струмені. При великих значеннях плазмового тиску $\left(\mathrm{P}_{0} \geq 75\right.$ Торр) на осі плазмового струменя поблизу підкладки утворюється згусток наночастинок 3 різкою межею. При взаємодії з цим згустком наночастинки, які рухаються в плазмовому струмені, втрачають спрямовану енергію, і їх потік на підкладку поблизу осі струменя дорівнює нулю. 